existing conditions and position in the past of southern Australia. It is of interest to note that some of the photographs illustrating the pamphlet have a marked resemblance to parts of West Africa on the south Saharan borderland. It is impossible here to follow the author throughout his investigations, but they may be summarized.

Mr. Ratcliffe holds the theory that the soil drift in Australia is chiefly, if not solely in parts, due to the excessive utilization of the soil by man, chiefly stock; that, in other words, the drift is the result of the disintegration of the soil layers in situ into loose particles which thus produce in the end a desert; that these desert conditions are not produced, or even assisted to any material extent, by sand or particles blown from neighbour. ing desert areas. He admits that this latter is the theory of the local farmers, who speak of the 'encroaching sand' or 'encroaching desert'. The author apparently holds strongly to his theory of the local origin sur place of the sand or drift resulting from the gradual deterioration of the soil.

It is difficult to follow this theory. May there not be a certain amount of sand invasion on to good stock grounds from areas outside which are in various stages of degradation down to pure desert conditions-as, in fact, is well demonstrated in the Sahara? Is there any great or sharp distinction between areas containing what Mr. Ratcliffe terms soil drift in Australia and the lands in the immediate vicinity of the Sahara on which the soil is still capable of producing a vegetation of use to man and his animals, but which gradually becomes overlaid with an ever-thickening carpet of blown sand ? Is not this a possible factor in Australia? It is difficult to credit the fact that in these deteriorating lands in South Australia the conversion to drift and aridity is practically entirely produced sur place, through the admittedly improvident actions of the occupiers of the land by excessive stock grazing and so forth.

The author, after a study of the literature on the problem of erosion elsewhere in the world, considers that "conditions in the Australian arid pastoral areas have no exact parallel elsewhere, and thus the problem of their deterioration must be tackled on its own merits". It is difficult to follow the argument. The resulting aridity leading up to desert conditions in several parts of the world is an outcome of the excessive activity of man and his wasteful utilization of the lands in question, with the inevitable result that the water supplies commence to become intermittent, and then cease, the spring water-level or the watertable sinking in the soil to a depth beyond its possible further utilization for his purposes. The ensuing conditions and their origin in modern times would appear to have a considerable similarity in the three regions of the globe already mentioned.

The remedies suggested by the author, with suitable modifications easily ascertainable in the region in question, appear equally applicable and called for in all. "Permanent pastoral settlement," says the author, "is only possible when the stocking is in equilibrium with the vegetation, and not merely exploiting plant capital"; and he urges the need for readjusting the stocking policy of the arid pastoral country. This is an equally pressing problem in parts of northern Nigeria and in the French Colonies bordering on the southern Sahara.

\title{
Geomorphology of the Irish Sea Basin
}

\author{
By Prof. J. Kaye Charlesworth
}

\begin{abstract}
A MORNING session of Section C (Geology) at the meeting of the British Association at Blackpool was devoted to a discussion of the geomorphology of the Irish Sea Basin. Although the discussion brought out perhaps little that was new, it outlined the main features of the evolutionary development which, treated historically, may have a wider appeal.

The Irish Sea-basin had its beginnings in the remote geological past. The sediments of the geosynclinal sea, which during Lower Palæozoic times obliquely crossed the site of the present
\end{abstract}

basin with shore-lines far beyond the present coasts to the north-west and south-east, were compressed into concertina and less acute folds at the close and elevated into a mountain system. At this remote date, the Irish Sea-basin appeared if only in shadowy outline, and there emerged the rim of mountains of hard rocks that, save in the Mournes then unborn, more or less surround the sea of to-day and exhibit in the trend of their valleys, ridges and geological strike lines, the north-east south-west Caledonian direction. The release of pressure probably initiated the tectonic 
subsidence of the Solway Firth and its continuation south of Co. Down that subsequent movements were later to accentuate, and gave rise to cross fractures, such as those which opened the southern part of the North Channel and the depression of the Dundonald valley and Strangford Lough.

The Carboniferous Limestone sea which transgressed the Old Red Sandstone desert that followed these events was in some respects the prototype of the present Irish Sea; its waters, as attested by shingle beaches, washed against the foot of the mountains of Down, Wicklow and Wales, the Lake District and the Isle of Man. The deltaic conditions that followed and led up to the Coal Measure swamps, with the aid of erosion, largely evened up the basin, so that at the end of the Coal Measure period probably but little of the elevations was left projecting. The succeeding American or Hercynian folding once again emphasized old tendencies and revivified the relief by doming the mountains along the old lines, as in Wales and Wicklow and the Lake District, where some of the Carboniferous Limestone doming must date from this time, and by dropping the rocks down along the periphery and re-opening posthumously the Caledonian fault-lines that ran north-west south-east.

The marine regressions and transgressions which, with their erosion and deposition, constitute the Mesozoic history of the basin doubtless re-fashioned this and partially effaced its earlier features. The close of the era indeed saw a plain emerge from the Cretaceous sea that was almost devoid of relief, though it was probably warped upwards over the sites of the ancient uplands and downwards over the Irish Sea and the Solway and Cheshire basins. The end of the Cretaceous is a datum-line of the utmost importance, for the present drainage, except in the region of the Tertiary igneous rocks of north-east Ireland, had its inception on the land-surface that then came into existence.

The Tertiary witnessed a further stage in the development of the basin as we know it. It saw the intrusion of the granites of the Mourne and Carlingford Mountains, which belatedly take their place in the enclosing rim. The foundering of the North Channel probably along its whole length and the opening of the Carlingford depression are of this date. Most important of all, however, the basin was the theatre of intermittent uplift. Periods of rest and planation are recorded in a number of peneplains which are beautifully developed throughout the basin. These periods were separated by others of downcutting and rejuvenation of rivers and of broad warping along the old lines when Wales and the Lake District, for example, were greatly domed and the Irish Sea floor between them and the Isle of Man was equally depressed. The planations still preserved to us include levels at about $1,800 \mathrm{ft}$., $600 \mathrm{ft}$., $400 \mathrm{ft}$. and $200 \mathrm{ft}$. above sea-level and, less certainly, at other heights. They seem to be later than the Tertiary igneous cycle of north-west Britain, for they cut across the igneous rocks in north-east Ireland and elsewhere intersect the dykes which extend from them. The last of the plains, of early Pliocene age, rises into the Central Plain of Ireland and extends through Co. Down and the coastal plains of Wicklow and Anglesey and underlies much of Cheshire and the Machars of Galloway. It was succeeded by still further uplift which enabled the rivers to cut gorges, now for the most part 'buried' or submerged. Towards the close of the Pliocene a reverse movement 'drowned' the lowest valleys and admitted the sea to a coastline which is still traceable in numerous places.

The Ice Age, the last chapter of this morphological history, did much to modify the topography which it inherited. Its glaciers sculptured the uplands, converted their V-shaped gorges into U-shaped valleys, hollowed out their floors into lakes, widened their heads into cwms and gave to the basin its only fiord, Carlingford Lough. The ice deposited its load as boulder-clay, drumlins, moraines and sands and gravels that mantle the plains and mask the Lias and Chalk which form much of the solid sea-bottom. It transformed the late Pliocene gorges into 'buried valleys', both within and without the present coast, concealed the preglacial shore-line along most of its length, and converted parts of the sea-floor into dry land, as in the Cheshire Plain, Vale of Clwyd, northern plain of the Isle of Man and the isthmus beneath Stranraer.

After the dissolution of the ice-sheets, the incoming temperate flora provided the forests which clothed so much of the surface when the sea was $100 \mathrm{ft}$. or more lower than now. A rise of the sea, due to general eustatic changes and to local movements of the crust, inundated these 'submerged forests' and isolated Ireland and the Isle of Man from Great Britain.

This age-long and never-ending evolution still continues. Running water is slowly paring down the land and dumping its detritus into the sea. The sea itself is wasting away the shores and silting up the bays and estuaries, and on-shore winds are piling up the dunes. The unstable ground is slowly tilting southwards, as is shown by the submergence of an occasional prehistoric site along the coast of Co. Cork and by the recent fine levellings of the Ordnance Survey in England. 